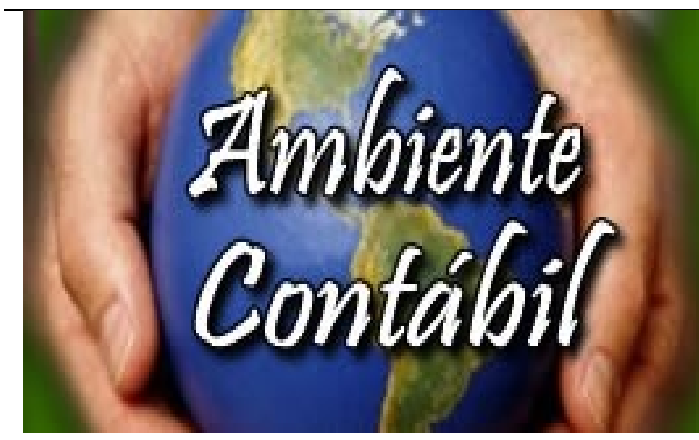

REVISTA AMBIENTE CONTÁBIL

Universidade Federal do Rio Grande do Norte

ISSN 2176-9036

Vol. 12, n. 1, Jan./Jun, 2020

Sítios: http://www.periodicos.ufrn.br/ambiente

http://www.atena.org.br/revista/ojs-2.2.3-06/index.php/Ambiente

Article received on: 07/22/2019 Reviewed by peers on: 09/11/2019 Reformulated on: 10/14/2019. Evaluated by the double blind review system.

DOI: $10.21680 / 2176-9036.2020 v 12 n 1 I D 19617$

Accounting teaching and the convergence process to international financial reporting standards

Enseñanza de ciencias contables y el proceso de convergencia a las international financial reporting standards

O ensino de ciências contábeis e o processo de convergência ao international financial reporting standards

\title{
Giovana Bolzan
}

Master's degree in Controlling and Accounting of Postgraduate Program at Federal University of Rio Grande do Sul (UFRGS). Address: Av. João Pessoa, 52, Accounting and Actuarial Department, Centro, 90040-000 - Porto Alegre, RS. Fone: (55) 51 98421-2878. Identifiers (ID): ORCID iD: https://orcid.org/0000-0002-7363-1183

Lattes: http://lattes.cnpq.br/0750766593360669

E-mail: bolzangiovana@gmail.com

\section{Maria Ivanice Vendruscolo}

$\mathrm{Ph} . \mathrm{D}$ in the Computers in Education of Postgraduate Program in Computers in Education (PPGIE) at Federal University of Rio Grande do Sul (UFRGS). Address: Av. João Pessoa, 52, Sala 28, Centro, 90040-000 - Porto Alegre, RS. Fone: (55) 51 33083506. Identifiers (ID):

ORCID iD: https://orcid.org/0000-0002-2132-5029

Lattes: http://lattes.cnpq.br/4692790971589040

Email: maria.ivanice@ufrgs.br

\section{Jonatas Dutra Sallaberry}

Ph.D Student in Accounting of Postgraduate Program at Federal University of Santa Catarina (UFSC). Address: Federal University of Santa Catarina PPGC - CSE, Bloco F, Campus Trindade, 88040-970 - Florianópolis, SC - Fone: (55) 41 98496-6447. Identifiers (ID):

ORCID: https://orcid.org/0000-0001-7492-727X

REDALYC: redalyc.org/autor.oa?id=21683

Lattes: http://lattes.cnpq.br/9920574928553347

Google Analytics UA-111870382-1

Email: jonatas.sallaberry@hotmail.com

\section{Willian Diehl}

Master's degree Student in Master in Controlling and Accounting of Postgraduate Program at Federal University of Rio Grande do Sul (UFRGS). Address: Av. João Pessoa, 52, Centro, 90040-000 - Porto Alegre, RS. Fone: (55) 51 99631-6877. Identifiers (ID): 
ORCID: https://orcid.org/0000-0002-7578-8379

Lattes: http://lattes.cnpq.br/3006870041717107

Email: willian.diehl@hotmail.com

\begin{abstract}
Purpose: The research analyzes the teaching of accounting sciences in view of the convergence with international accounting standards, from the perspective of scientific production.
\end{abstract}

Methodology: In the study, the approach of the problem occurs in a qualitative and quantitative methods, concerning the objective in a descriptive way and, regarding the technical procedures, the identification of 21 articles on "teaching" and "IFRS" in the period from 2007 to 2018 , which were support for the documental analysis and systematic review. In the development of the proposal, we used content analysis procedures with the categorization of the articles, and their contributions to the discussion.

Results: The results indicate the concern with the curriculum, faculty members and students in the teaching process, in relation to the perception and the acquisition of knowledge. Problems and limitations have been identified in both students and faculty members, but with more consistent results in farther periods from the beginning of convergence to international accounting standards. With Regard to the research, the main researchers of the joint theme Teaching and IFRS, Jorge Niyama, Dulcinéli Botelho and Roberto Carlos Klann, and other authors whose publications on the subject occurred in high quality journals. In general, research on the subject allows the development of networks with the predominance of doctors researchers and space for other researchers in training.

Contributions of the Study: The study reveals the difficulties faced by faculty members and students in the incorporation of new accounting principles and the assimilation of knowledge, indicates gaps in the need for training and improvements in the teaching process in order to increase the quality of accounting teaching. In addition, it indicates potential research gaps and demonstrates that the subject absorbs even researchers in training about research conducted by doctors, denoting the importance of research groups and networks.

Keywords: Teaching. Convergence. IFRS. International Standards.

\title{
Resumen
}

Objetivo: La investigación analiza la enseñanza de las ciencias contables en vista de la convergencia con los estándares internacionales de contabilidad, desde la perspectiva de la producción científica.

Metodología: En el estudio, el enfoque del problema se produce de forma cualitativa y cuantitativa, con respecto al objetivo de forma descriptiva y, con respecto a los procedimientos técnicos, la identificación de 21 artículos sobre "enseñanza" y "NIIF" en el período comprendido entre 2007 hasta 2018, que fueron soporte para el análisis documental y la revisión sistemática. En el desarrollo de la propuesta, utilizamos procedimientos de análisis de contenido con la categorización de los trabajos y sus contribuciones a la discusión.

Resultados: Los resultados muestran la preocupación por el currículo, los profesores y los estudiantes en el proceso de enseñanza, en relación con la percepción y la adquisición de conocimientos. Se han identificado problemas y limitaciones tanto en los estudiantes como en 
los maestros, pero con resultados más consistentes en períodos más alejados del comienzo de la convergencia a los estándares internacionales de contabilidad. Respecto a las investigaciones, los principales investigadores del tema conjunto Docencia y NIIF, Jorge Niyama, Dulcinéli Botelho y Roberto Carlos Klann, y otros autores cuyas publicaciones sobre el tema se publicaron en revistas de alta calidad. En general, la investigación sobre el tema permite el desarrollo de redes con predominio de investigadores y espacio para otros investigadores en formación.

Contribuciones del Estudio: El estudio, que revela las dificultades que enfrentan maestros y estudiantes en la incorporación de nuevos principios contables y la asimilación de conocimientos, indica brechas en la necesidad de capacitación y mejoras en el proceso de enseñanza para aumentar la calidad de la educación contable. Además, señala los posibles vacíos de investigación y demuestra que el sujeto absorbe incluso a los investigadores en formación en investigación llevada a cabo por médicos, lo que denota la importancia de los grupos y las redes de investigación.

Palabras clave: Enseñanza. La convergencia NIIF. Normas Internacionales.

\section{Resumo}

Objetivo: A pesquisa analisa o ensino de ciências contábeis diante da convergência aos padrões internacionais de contabilidade, sob a perspectiva da produção científica.

Metodologia: No estudo, a abordagem do problema ocorre de forma quali-quantitativa, quanto ao objetivo de forma descritiva e, no que tange aos procedimentos técnicos, a identificação de 21 artigos sobre "ensino" e "IFRS" no período compreendido entre os anos de 2007 a 2018 , que foram suporte para a análise documental e revisão sistemática. No desenvolvimento da proposta empregou-se procedimentos de análise de conteúdo com a categorização dos trabalhos, e suas contribuições para a discussão.

Resultados: Os resultados evidenciam a preocupação com o currículo, os docentes e discentes no processo de ensino, em relação a percepção e à aquisição de conhecimentos. Foram identificados problemas e limitações tanto em discentes como em docentes, mas com resultados mais consistentes em períodos mais distantes do início da convergência aos padrões internacionais de contabilidade. No que tange às pesquisas, os principais pesquisadores do tema conjunto Ensino e IFRS, Jorge Niyama, Dulcinéli Botelho e Roberto Carlos Klann, e demais autores cujas publicações sobre o tema ocorreram em periódicos de elevada qualidade. Em geral, pesquisas sobre a temática permitem o desenvolvimento de redes com a predominância de pesquisadores doutores e com espaço para os demais pesquisadores em formação.

Contribuições do Estudo: O estudo ao revelar as dificuldades enfrentadas pelos docentes e discentes na incorporação dos novos preceitos contábeis e da assimilação do conhecimento, indica lacunas de necessidade de capacitação e de melhorias no processo de ensino a fim de ampliar a qualidade do ensino contábil. Além disso, sinaliza potenciais lacunas de pesquisa e demonstra que a temática absorve inclusive pesquisadores em formação em pesquisas conduzidas por doutores, denotando a importância dos grupos e das redes de pesquisa.

Palavras-chave: Ensino. Convergência. IFRS. Normas Internacionais. 


\section{Introduction}

Accounting has undergone constant and rapid changes. The increase in international trade relations, coupled with the increase in competitiveness in the markets, has sparked frequent discussions about the need for changes in accounting standards, minimizing information asymmetry problems. The search to unify it, for applicability in any environment and understanding by different types of users, besides the possibility of comparability of information culminated in the process of convergence with international accounting standards (Gill, 2007).

As an academic area, it was initially established with an extremely normative character and focused on the recommendation of professional practices and procedures. This tradition, however, was replaced by the information approach, which represented a revolution and change of research paradigms (Lopes \& Martins, 2014), breaking with the view of Accounting as measurement and developing the study of information available to users. Financial statements, before being based on definitions and inferences, started to be based on the usefulness of information for specific users, explaining and predicting accounting practices (Watts \& Zimmerman, 1986).

It is in this context that the International Financial Reporting Standards (IFRS) are inserted, which standards are relevant for the education of accounting professionals. However, for this training of the accounting professional to be carried out properly, it is necessary that faculty members, as mediators of the teaching and learning process develop technical skills and master the specific contents of the discipline, in order to encourage students to reflect and search for new knowledge (Vasconcelos, 1996; Vendruscolo, 2015).

The Accounting Pronouncements Committee (O Comitê de Pronunciamentos Contábeis $-C P C$ ) continues to issue revisions and new standards; for some authors, however, the convergence process (or its most critical stage) would have already been completed in Brazil (Costa, Theóphilo, \& Yamamoto, 2012; Silva, Borges, Gonçalves, \& Nascimento, 2017). During this period, higher education is undergoing decline, facing a crisis of student demand (Semeasp, 2018) and quality, given the evaluation results of education, such as Enade (Fajardo $\&$ Frederico, 2015) and the Sufficiency Exam (CFC, 2019), where results have been lower or kept at low levels. Several factors can influence the quality of teaching, including expanded with the incorporation of new content that requires new skills such as interpretation of the standard, replacement and updating of content, training of faculty members, directly or indirectly.

Therefore, the present research seeks to answer the following question: how did the teaching of Accounting incorporate the changes resulting from convergence to IFRS, from the perspective of scientific publications found in CAPES and SPELL journals that address themes such as teaching and IFRS in Brazil? This is in order to obtain the several evidences that the studies present about the convergence process, which define the incorporation process; 'How' the convergence took place, even being stages, difficulties or opportunities.

This adoption tends to affect the curriculum, assessment process, teaching methods, and teaching management, and recognizing the state of the art through a set of publications may reveal broader directions for teaching and related research than primary empirical research, whose scope is more punctual.

Due to the change from the national Accounting standard to the international model, this current inquiry becomes timely, upon a time window of more than 10 years, as suggested by Araújo et al. (2014). Thus, the aim of the present study is to analyze the teaching of accounting sciences in face to the convergence with international accounting standards, from the 
perspective of scientific production. The topic becomes relevant, given the fact that the quality and credibility of accounting information are directly associated with the quality of accounting education in the accounting area. (Barth, 2008; Cella, Rodrigues, \& Niyama, 2011; Machado \& Nakao, 2014; Nunes, Marques, \& Costa, 2016). In addition, the researches may provide findings that contribute to point educational solutions for new changes in accounting standards, or even to incorporations of international standards.

The paper is divided into three sections beyond this introduction. The theoretical platform can be found in section 2 and then the methodological procedures are presented, followed by the results obtained and the discussion and confrontation with the theoretical framework. Finally, the final considerations and suggestions for future investigations are made.

\section{Theoretical Referential}

The dissemination of Positive Accounting Theory from the 1960s revolutionized research paradigms, breaking the view of Accounting as a measurement and developing the study of information available to users (Watts \& Zimmerman, 1986), taking different directions in the United States and in Europe and promoting accounting divergences between countries (Weffort, 2005; Epstein \& Mirza, 2006). However, the strengthening of relations between nations, the internationalization and interconnection of markets has brought to light the need for accounting standards that can reduce the differences between accounting information and allow its comprehension in a globalized way (Niyama \& Silva, 2013).

The process of adopting IFRS has brought to light the need for Higher Education Institutions (HEIs) to adapt to the new reality arising from these changes (Riccio \& Sakata, 2004), since the quality of Accounting education has the ability to influence the effectiveness of the convergence process in a country (Ding, Hope, Jeanjean, \& Stolowy, 2007) and that new demands on the practices of accounting professionals suggest the adoption of new educational paradigms with the inclusion of teaching mechanisms and didactics in pedagogical practice (Silva, Santos, Cordeiro Filho, \& Bruni, 2014).

In Brazil, the process of convergence to the IFRS standard was initiated in 2005, with the implementation of the CPC, and the publication of Law No. 11,638, which amended the Brazilian Corporate Law (Martins, Gelbcke, Santos, \& Iudicibus, 2013). The adoption of these standards brought significant changes to the accounting process, such as changes in measurement, recognition and disclosure criteria (Martins et al., 2013; Lopes \& Martins 2014).

This scenario has allowed greater transparency of information; however, it has required professionals who are better prepared and able to adapt to the new accounting standards (Lopes \& Martins, 2014). This is because accounting education has a significant impact on the quality and on the type of information generated by the accounting system and in narrowing the gap between higher education and the professional skills required by the labor market (Mohamed \& Lashine, 2003; Niyama, 2010).

Accounting education has been undergoing major changes worldwide and not only in Brazil, signaling the importance of continuing professional development (Marion, 2001; Laffin, 2001; Needles Jr et al., 2001; Howieson, 2003; Becker, 2010; Marshall et al ., 2010; Vendruscolo, 2015). The State regulation already provides guidelines for the pedagogical conception of the courses, the curricular organization to be established, the duration, the practical and complementary activities, the desired profile of the egress, among other orientations that may help the management of the courses (Brasil, 2004).

In the area of accounting education, the role of the professor is fundamental in this context of changes, in order to develop professional skills. Vendruscolo (2015) points out that, within the scope of faculty skills, specifically the technique, the faculty member is required to master certain knowledge, such as: contents of the specific knowledge area, related theories and 
fields of knowledge, professional experience, interdisciplinarity, principles and Accounting standards, internationalization of accounting standards, code of ethics of the accounting profession, organizations and businesses.

According to the study by Matos, Niyama, Fernandes, \& Botelho (2012), internationally, researches related to "education" and "instruction" reveals concerns about education and the higher education process. Instead of memorizing rules, students need to learn to judge financial information (Barth, 2008), which is directly associated with educational issues. It is in this context, then, that challenges arise related to the qualification of the faculty, the qualification of the students and the curricular structure.

Despite this, it appears that rapid changes in the business environment contrast with slow changes in the field of accounting education, so that the discontent with the current Accounting education system has led the academic community to rethink and discuss the teaching process in order to seek its improvement and constant updating. This is one of the biggest challenges face by Brazil in the convergence process and, according to Matos, Gonçalves, Niyama and Marques (2013), an opportunity to transform education and the accounting class.

A faculty's career is an ongoing process that includes adapting to changes in the subject to contribute to student learning. During the convergence process the concepts of IFRS were being incorporated into the academy from the international standard (Nascimento, Lopes, Colauto, \& Pederneiras, 2014). Damascena, Duarte, \& Paulo (2007) encourage researches on the full adoption of IFRS in Brazil, which necessarily implies their teaching, while other authors seek to reveal changes and improvements in the characteristics of financial statements after adoption of international standards (Ettore, Silva , Macedo, 2017; Machado, Victor, Mattis, 2016; Sousa \& Santos, 2017; Zortea, Galdi, Monte-mor, \& Beiruth, 2017).

The Accounting Science undergraduate course (curso de graduação em Ciências Contábeis) should be structured to include basic, professional and theoretical-practical training (Brazil, 2004), and the correct approach to the content needs to be contemplated in the pedagogical project. To attend the demands of the globalized market, accounting teaching must go beyond the professionalization proposed by the training axes, advancing on the broader issues that develop a critical profile in future accountants (Laffin, 2002; Hernandes, Peleias, \& Barbalho, 2006; Vendruscolo, 2015).

The training should reveal a range of competencies that reflect scientific, technical, social, economic and financial issues, nationally and internationally and in different organizational models (Brazil, 2004), with capacity for critical analysis, decision making and greater sensitivity to political, economic and social aspects (Miller \& Becker, 2010). The faculty member must anticipate the changes expected by the labor market in the skills of accountants (Howienson, 2003), however contemporary change is already a major challenge.

Even in terms of convergence with IFRS, which international Accounting organizations have been concerned with training and subsidizing professors with research, support materials and educational activities (Passos, 2011), the bibliography and updating of faculty members is a critical and broad element, because many of the alterations affect the accounting process as a whole, which requires the full updating of the faculty members.

Another side of great relevance is the student's gaze, as it is the subject object of the teaching process, and if it does not acquire the skills and abilities, less will reflect on the transformation of the individual. Amid subjective competencies that need to be transmitted to the student include judgment, communication, research and understanding (Vendruscolo, 2015). Given this scenario, the role of the professor acquires a complexity and theoretical scope, professional and pedagogical experiences (Laffin, 2001).

Training should prepare for a pedagogical practice that invests in human beings and enable the future professional for the labor market (Zabala, 1998; Nossa, 1999). We highligh 
the need for a faculty education focused on the theoretical reflection on the pedagogical and professional practice of accounting professors. (Laffin, 2001; Miranda, 2011).

\section{Methodological Procedures}

Regarding to the approach of the problem, the study is qualitative and quantitative because it analyzes the aspects of the significance elements defined in the categories of content analysis while the quantitative aspects derive from the quantification of the elements of authorship and form, which by their frequency also denote the relevance, a typically qualitative feature. In terms of results it adopts a descriptive definition, in relation to the scientific production on teaching in Accounting and, by technical procedure the documental (Raupp \& Beuren, 2013; Silva, 2003) and content analysis (Bardin, 2016).

The content analysis technique allows a phenomenological perspective for data collection and interpretative analysis (Bardin, 2016). This technique implies the adoption of analysis categories, described in the table, combined with coding for extraction and organization of data used in the subsequent analysis (Bardin, 2016). The articles were classified into subject categories based on the criteria presented in Table 1 and analyzed by the predominant theme of each paper, even though there was more than one.

Table 1

Description of sample analysis categories

\begin{tabular}{l|l}
\multicolumn{1}{c}{ Categories } & \multicolumn{1}{c}{ Description } \\
\hline Curriculum Analysis & $\begin{array}{l}\text { Articles that identify characteristics of the curriculum structure related to the } \\
\text { teaching of IFRS. }\end{array}$ \\
\hline Publication Analysis & $\begin{array}{l}\text { Articles that analyzed and identified themes and publications of accounting } \\
\text { teaching under IFRS. }\end{array}$ \\
\hline $\begin{array}{l}\text { Student- Knowledge } \\
\text { Assessment }\end{array}$ & $\begin{array}{l}\text { Articles that assessed the level of knowledge of accounting students about } \\
\text { IFRS. }\end{array}$ \\
\hline $\begin{array}{l}\text { Student - Perception } \\
\text { Assessment }\end{array}$ & Articles that analyzed students' perceptions of the convergence process. \\
\hline $\begin{array}{l}\text { Faculty } \\
\text { Knowledge assessment }\end{array}$ & $\begin{array}{l}\text { Articles that assessed the level of faculty's accounting knowledge regarding } \\
\text { IFRS. }\end{array}$ \\
\hline $\begin{array}{l}\text { Faculty Member - Perception } \\
\text { Assessment }\end{array}$ & $\begin{array}{l}\text { Articles that analyzed faculty members' perceptions of the convergence } \\
\text { process. }\end{array}$ \\
\hline $\begin{array}{l}\text { Student and Faculty Member } \\
\text { - Knowledge assessment }\end{array}$ & $\begin{array}{l}\text { Articles that assessed the knowledge level of accounting students and faculty } \\
\text { members regarding IFRS. }\end{array}$ \\
\hline $\begin{array}{l}\text { Student and Faculty Member } \\
\text { - Perception assessment }\end{array}$ & $\begin{array}{l}\text { Articles that analyzed student and faculty member perception about the } \\
\text { convergence process. }\end{array}$ \\
\hline
\end{tabular}

Source: Research Data (2019).

The research population is the set of articles published in national journals related to Accounting from 2007 to 2018, a window of more than 10 years after the beginning of the convergence. To consult the journals, we used the database of the Academic Level Education Personnel Training Committee (Comissão de Aperfeiçoamento de Pessoal do Nivel Superior) (CAPES) and the Scientific Periodicals Electronic Library (SPELL). For the selection criteria, the keywords "accounting convergence", "international standards" and "IFRS" combined with "teaching", "education" and "Accounting", were used together or separately.

The search resulted in 61 articles selected by reading the abstract and keywords to verify the link with the research topic. The resulting sample consisted of 21 articles that were completely read and classified in a database prepared in Microsoft Office Excel with data regarding: (a) title, (b) authorship, (c) year of publication, (d ) journal, (e) keywords, (f) research problem, (g) purpose, (h) sample, (i) methodology, and (j) results. From the characteristics 
survey of each article, the bibliometric analysis was performed to identify and enhance the discussions inherent to the characteristics of the studies on "Teaching and IFRS".

From a content analysis on the topics "research problem" and "purpose", the articles were classified into subject categories and subcategories (Bardin, 2016). This classification sought to segregate the scientific production, since the analyzed articles had different approaches to accounting teaching.

Finally, the research resulting from the analysis is discussed in view of their contributions to the area, highlighting convergent and divergent aspects and showing any gaps that may be the subject of future research.

\section{Data Analysis}

In order to understand the general characteristics of the sample, the main characteristics of publications, journals and their authors are highlighted. Table 2 illustrates the journals from which articles were extracted to compose the study sample, described by titles, ISSN, and citation of the corresponding publications.

Table 2

Statement of sample journals based on data from 2007 to 2018

\begin{tabular}{|c|c|c|c|}
\hline Periodical & ISSN & Quantity & Authors \\
\hline Revista Universo Contábil & $1809-3337$ & 3 & $\begin{array}{c}\text { Nunes, Marques, \& Costa (2016) } \\
\text { Niyama, Mendonça, \& Aquino (2007) } \\
\text { Araújo, Cornacchione Junior, Reginato, \& Suzart (2014) }\end{array}$ \\
\hline $\begin{array}{l}\text { Revista Contabilidade e } \\
\text { Controladoria }\end{array}$ & $1984-6266$ & 3 & $\begin{array}{c}\text { Machado, Kuhn, \& Machado (2014) } \\
\text { Fernandes, Lima, Vieira, \& Niyama (2011) } \\
\text { Amaral, Costa, \& Campos (2010) }\end{array}$ \\
\hline $\begin{array}{l}\text { Revista Contemporânea de } \\
\text { Contabilidade }\end{array}$ & $2175-8069$ & 2 & $\begin{array}{c}\text { Cella, Rodrigues, \& Niyama (2011) } \\
\text { Alves, Kronbauer, Ott, \& Thomaz (2017) }\end{array}$ \\
\hline ConTexto & $2175-8751$ & 2 & $\begin{array}{c}\text { Matos, Niyama, Fernandes, \& Botelho (2012) } \\
\text { Ettore, Silva, \& Macedo (2017) }\end{array}$ \\
\hline $\begin{array}{l}\text { Revista Contabilidade e \& } \\
\text { Finanças }\end{array}$ & $1808-057 \mathrm{X}$ & 1 & Costa, Gomes, Braunbeck, \& Santana (2018) \\
\hline $\begin{array}{l}\text { Contabilidade Vista \& } \\
\text { Revista }\end{array}$ & $0103-734 X$ & 1 & Marassi, Fasolin, \& Klann (2018) \\
\hline $\begin{array}{c}\text { Revista de Contabilidade } \\
\text { do Mestrado em Ciências } \\
\text { Contábeis da UERJ }\end{array}$ & $1984-3291$ & 1 & Kuhn, Machado, \& Machado (2014) \\
\hline $\begin{array}{l}\text { Revista de Contabilidade e } \\
\text { Organizações }\end{array}$ & $1982-6486$ & 1 & Niyama, Botelho, Corrêa, \& Santana (2008) \\
\hline$R A C E$ & $2178-7638$ & 1 & Reis, Nogueira, \& Bim (2014) \\
\hline Revista Ambiente Contábil & $2176-9036$ & 1 & Nascimento, Lopes,Colauto, \& Pederneiras (2014) \\
\hline GECONT & $2358-1735$ & 1 & Lima, Costa, \& Santana (2015) \\
\hline Revista da Unifebe & $2177-742 \mathrm{X}$ & 1 & Toigo, Vogt, Degenhart, \&Klann (2014) \\
\hline $\begin{array}{c}\text { Revista de Administração, } \\
\text { Contabilidade e } \\
\text { Sustentabilidade } \\
\end{array}$ & $2237-3667$ & 1 & Gomes, Cruz, Souza, \& Gomes (2015) \\
\hline Sociais e Humanas & $2317-1758$ & 1 & Lunedo, Kruger, Mazzioni, Lunedo, \& Folletto (2014) \\
\hline
\end{tabular}




\begin{tabular}{|c|c|c|c|}
\hline \multicolumn{4}{|c|}{ Giovana Bolzan, Maria Ivanice Vendruscolo, Jonatas Dutra Sallaberry and Willian Diehl } \\
\hline Pensar Contábil & $1519-0412$ & 1 & Cunha, Guidini, \&Klann (2017) \\
\hline Total & & 21 & \\
\hline
\end{tabular}

Source: Research Data (2019).

Publications were found in 15 different journals (Table 2); however, four journals concentrate $48 \%$ of the sample - Journal of Accounting and Controlling (Revista Contabilidade e Controladoria), Journal of Accounting Universe (Revista Universo Contábil) and Journal of Contemporary Accounting (Revista Contemporânea de Contabilidade)- linked respectively to the Graduation Programs (Programas de Pós-Graduação-PPG) of the Federal University of Paraná (da Universidade Federal do Paraná), Regional University Foundation of Blumenau (Fundação Universidade Regional de Blumenau) and Federal University of Santa Catarina (Universidade Federal de Santa Catarina), all Graduation Programs (Programas de PósGraduação-PPG) evaluated by the Ministry of Education (Ministério da Educação-MEC), in 2017, with grade 5, in addition the ConTexto Journal (Revista ConTexto), linked to the recent Master's degree from the Federal University of Rio Grande do Sul (Universidade Federal do Rio Grande do Sul). The others published only one article in each journal, over a period of 11 years, revealing a concentration approach of few journals with significant amount and capillarity, because the theme reached 15 journals (Mattos, 2004).

These results highlight the artifacts of the discussion about the scientific quality of knowledge (Mattos, 2004), because the approach of the theme was identified in journals linked to high quality institutions perceived by the regulatory agency, not necessarily the researchers of these institutions. This may indicate that journals (although under the editor's bias) are connected with current topics related to educational practice.

This research reveals that journals from the three top-ranked Graduation Programs $(P P G)$ universities pay special attention to the reflections of international teaching standards. From the widening of the temporal window of analysis, such findings show the overcoming of limitations perceived by the results presented by Miranda et al. (2013), when analyzing publications on "accounting education" in the Journal of Accounting and Finance (Revista de Contabilidade e Finanças) and Journal of Education and Research in Accounting (Revista de Ensino e Pesquisa em Contabilidade), and did not identify articles with common pieces to "education" and "IFRS", or the similar terms.

\subsection{Research Analysis}

The growth of scientific production highlighted by Nganga, Botinha, Miranda, \& Leal (2016) is indicated as a consequence of the expansion of Graduation Programs (Programas de Pós-graduação-PPG). Teaching and research assignments are the most influential experiences in skills acquisition, which demands that the $P P G$ be aligned with the Teaching theme (Miranda, 2010). The journals in which the 21 articles subject to this analysis are published have predominant scope in the area of Accounting or in segments of the Social Sciences; none have as their main scope or focus in teaching or education in Accounting.

Taking into account the Qualis CAPES concept in the Accounting / Administration area, it was found that $38 \%$ of the articles in the sample (8) are currently indexed in journals classified as 'A2', admittedly higher strata (Almeida et al., 2017; Pazetto, Santos, \& Beuren, 2019). If we considered the classification at the time of publication, or the triennium 2010-2012 for articles published up to 2012, only one of these articles would be classified as published in a 'A2' journal. This reveals an evolution in the recognition of journals that have published articles related to "IFRS and teaching", possibly adopting editorial policies to adopt emerging and contemporary themes. Table 3 also presents the stratification of the articles used in the sample in the areas of education and teaching. 
Table 3

Classification of Sample Journals by CAPES Stratification

\begin{tabular}{c|c|c|c|c}
\hline Qualis & $\begin{array}{c}\text { ADM Area } \\
\text { 2013-2016 }\end{array}$ & $\begin{array}{c}\text { EDUC Area } \\
\text { 2013-2016 }\end{array}$ & $\begin{array}{c}\text { TEACHING Area } \\
\text { 2013-1016 }\end{array}$ & $\begin{array}{c}\text { ADM Area } \\
\text { Publication }\end{array}$ \\
\hline A2 & 8 & & & 3 \\
\hline B1 & & 1 & & 5 \\
\hline B2 & 3 & & 1 & 2 \\
\hline B3 & 5 & 1 & 1 & 7 \\
\hline B4 & 5 & 3 & & \\
\hline B5 & & 2 & & \\
\hline C & & 1 & & \\
\hline
\end{tabular}

Source: Research Data (2019).

As shown in Table 3, only a portion of the articles (9) are published in journals that were evaluated in the areas of Education and Teaching; all with assessments in lower quality strata or recognition, according to the criteria referred of the thematic areas. Thus, although accounting discusses accounting teaching and education, this discussion is not an influence in the main areas of teaching and education. Pierre, Wilson, Ravenscroft, and Rebele (2009) indicate that there would be publishers of Accounting journals who would refuse to work exclusively on education, although in the accounting field, nevertheless, in the national scenario, the education-oriented articles as evidenced only in articles related to "Teaching" in the background of "IFRS" demonstrates a different behavior from that indicated by Pierre et al. (2009).

Another relevant aspect in relation to academic production in "IFRS and Teaching" are the profiles of the identified authors, facing the challenges of faculty with research (Miranda, 2010). The 21 articles published contain 75 (seventy-five) authorships, representing an average of 3.6 authorships per publication. Among the authors, researchers with doctorate and postdoctorate degrees predominate $(30 \%)$. It is interesting to highlight that the theme adheres to the development of researchers, as it can be seen from the number of authors who can be considered "in training" with qualifications from undergraduate student (bacharelando) to doctoral students (doutorando) (Table 4), which tends to allow significant oxygenation of the knowledge area, and allow to expand knowledge in research and teaching. Except for two publications, in all the others one of the authors had a doctorate degree.

Table 4

Sample of Authors Titling Description

\begin{tabular}{c|c|c}
\hline Publication Title & Quantity & Frequency \\
\hline Undergraduate student & 5 & $7 \%$ \\
\hline Bachelor degree & 8 & $12 \%$ \\
\hline Specialist & 3 & $4 \%$ \\
\hline Master (Graduate) Student & 3 & $4 \%$ \\
\hline Master & 13 & $19 \%$ \\
\hline Doctoral Student & 15 & $22 \%$ \\
\hline Doctor (PhD) & 18 & $4 \%$ \\
\hline Post Doctor & 3 & $100 \%$ \\
\hline Total & 68 &
\end{tabular}

Source: Research Data (2019). 
The Graduation Programs ( $P P G$ ), in their role of training researchers, naturally seek to encourage and pursue to develop research skills in their students (Miranda, 2010), the research emphasizes that the programs are succeeding in this process. The pulverization between journals is also reflected among the authors, although there is appreciation of the networks. The main authors identified in quali-quantitative terms were Jorge Katsumi Niyama, Ducineli Régis Botelho and Roberto Carlos Klann, the most lucrative authors on the theme of "IFRS and Teaching", as shown in Table 5.

Table 5

Description of the Most Profitable Authors in "IFRS and Teaching"

\begin{tabular}{c|c|c}
\hline Author & Quantitative & Quali - ADM 2013-2016 \\
\hline Jorge Katsumi Niyama & 5 & A2, A2, A2, B3, B4 \\
\hline Ducineli Régis Botelho & 3 & A2, A2, B4 \\
\hline Roberto Carlos Klann & 3 & A2, B2, B4 \\
\hline Patrícia de Souza Costa & 2 & A2, A2 \\
\hline Cláudio Moreira Santana & 2 & A2, B4 \\
\hline Michele Rílany Rodrigues Machado & 2 & B2, B4 \\
\hline Jaqueline Kuhn & 2 & B2, B4 \\
\hline Lúcio de Souza Machado & 2 & B2, B4 \\
\hline
\end{tabular}

Source: Research Data (2019).

Observing as a parameter the quality indicators of journals in the area of Public and Business Administration, Accounting and Tourism, the authors with the highest scores were Jorge Katsumi Niyama, Ducineli Régis Botelho and Claudio Moreira Santana, who have joint publications, this highlights the importance of research networking and the consolidation of thematic research groups. However, such ranking does not include punctuation related to the teaching area, or with focus on the subject, unlike in the international scope, whose specialization of journals, such as the Journal of Accounting Education shows that there is punctuation related to the teaching area (Matos et al ., 2012).

The sample approached, including a bibliographic study, a case study and a teaching case. Except for the years 2009 and 2013, at least one article per year was published. In 2011, 2015 and 2018, two articles were published and in 2014 there were 7 publications, $38.8 \%$ of the sample, as shown in Figure 1. 


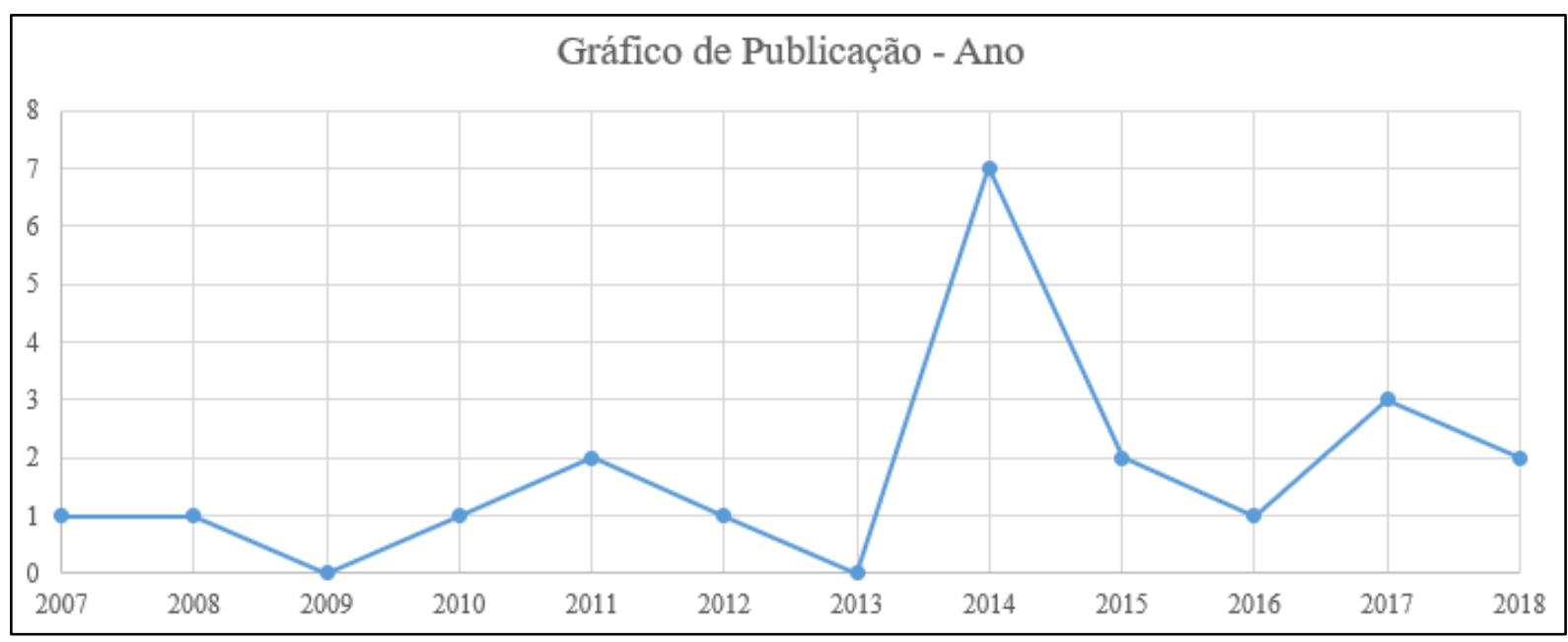

Figure 1 Publication Chart

Source: Research Data (2019).

This quantitative variation of publications can be partially explained by the transformations resulting from the expansion of Graduation Programs $(P P G)$ in Accounting and international Accounting standards (Miranda et al., 2013).

\subsection{Content Analysis}

The analysis of the content of the sample articles allowed us to evaluate the themes approached in each publication. It was found that $44 \%$ of the articles contained keywords related to international accounting standards and the convergence, while $32.9 \%$ contained keywords related to teaching of accounting, education, faculty members and students, highlighted in Table 6.

\section{Table 6}

List of keywords of the sample articles from 2007 to 2018

\begin{tabular}{lc}
\hline Keywords identified in articles related to & Number of Keywords \\
\hline International standards, convergence, harmonization and pronouncements & 31 \\
Teaching of accounting, education, faculty members e students & 23 \\
Other & 16 \\
\hline Total & $\mathbf{7 0}$ \\
\hline
\end{tabular}

Source: Research Data (2019).

These keywords are related to those used to select the articles that composed the sample of the present study in the CAPES databases. Nevertheless, expanding the analysis to the global topics of the various articles reveals a broader interaction of research, which may be aligned with a broader impact of the influence of changes that IFRS has brought to education, as shown in Figure 2. 


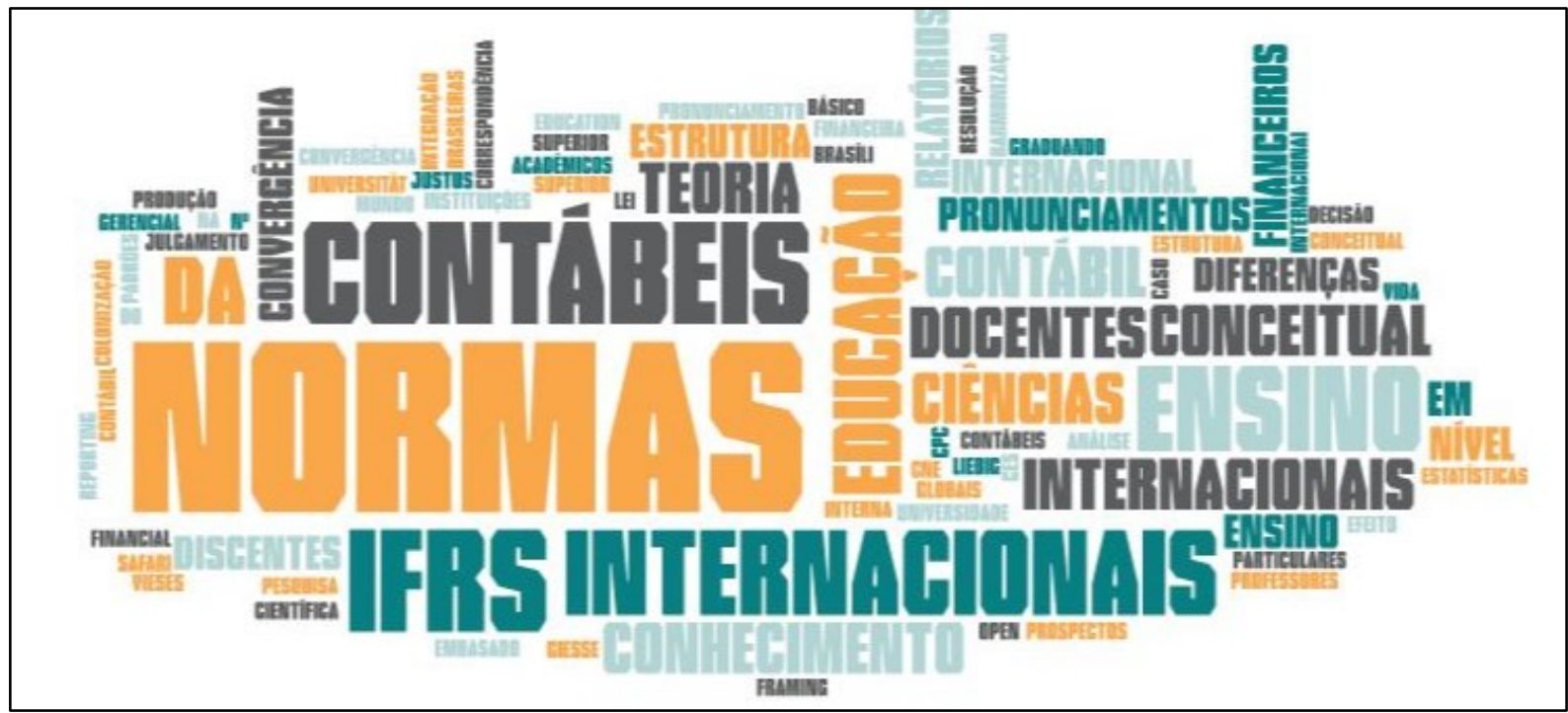

Figure 2 Word Cloud - Teaching Relations and IFRS

Source: Research Data (2019).

The articles were also analyzed in relation to the described methodology. The identification of the methodological types applied in each area of accounting education study is an important tool for improving the understanding of the methodologies used and possibilities for future studies for different themes, with different and complementary approaches (Matos et al. 2012).

Regarding the objectives, most articles were classified as descriptive, followed by exploratory research. No explanatory research was found. Concerning the procedures, more than $50 \%$ of the sample used a survey through questionnaires as a data collection procedure. The second most used type of research was documental.

The result of the analysis of the articles, according to the categories described in the methodology, is presented in Table 7. At the level of subject categories, "faculty member" is the one with the highest representativeness - 38.9\% of the analyzed articles adopted this perspective of analysis. With less representation of this item, there are subjects such as student, analysis of publications and curriculum analysis, with $22.2 \%, 16.7 \%$ and $16.7 \%$ of publications on each subject. The only article that addressed faculty member and student analysis concomitantly - provided a perception assessment.

\section{Table 7}

Classification of articles by subject

\begin{tabular}{c|c|c|c|c}
\hline Subject categories & Subject Subcategories & $\begin{array}{c}\text { Number of } \\
\text { articles by } \\
\text { subcategories }\end{array}$ & $\begin{array}{c}\text { Percentage } \\
\text { articles by } \\
\text { subcategories }\end{array}$ & $\begin{array}{c}\text { Percentage } \\
\text { articles by } \\
\text { subject }\end{array}$ \\
\hline Curriculum Analysis & & 3 & $16,7 \%$ & $16,7 \%$ \\
\hline Publications Analysis & & 3 & $16,7 \%$ & $16,7 \%$ \\
\hline \multirow{2}{*}{ Student } & Knowledge assessment & 3 & $16,7 \%$ & $22,2 \%$ \\
\hline \multirow{2}{*}{ Faculty Member } & Perception assessment & 1 & $5,6 \%$ & $16,7 \%$ \\
\hline Student and Faculty & Knowledge assessment & 3 & $22,2 \%$ & $38,9 \%$ \\
Member & Perception assessment & 4 & $0,0 \%$ & $5,6 \%$ \\
\hline Total & Perception assessment & 1 & $5,6 \%$ & $\mathbf{1 0 0 \%}$ \\
\hline
\end{tabular}

Source: Research Data (2019). 
There was only one article that presented the student perception about the convergence process in the field of teaching of Accounting. No article approached, simultaneously, assessment of knowledge of students and faculty member. Two articles were found that did curriculum analysis and two that brought assessment of faculty' knowledge about IFRS.

The data from the study verified that although initially the sample (21 articles) seems a little representative in relation to the number of articles published in recent years on the theme international convergence as a whole, it indicates a particular universe in the field of teaching briefly presented by Matos et al. (2012). According to Niyama (2010) the quality of accounting education has a significant impact on the quality and type of information generated for society, mainly by three factors: few are the higher education courses of excellent quality, few are the faculty members with appropriate academic qualifications and few are the participation and influence of the academy and the accounting profession on the financial reporting standards.

\subsection{The Convergence to International Accounting Standards and the Teaching}

Matos et al. (2012) revealed that research on international accounting education is growing, especially on curriculum, instruction and teaching methods, applying predominantly empirical/practical methods. Cella, Rodrigues and Niyama (2011) Informed that in international journals the main topics related to research are: continuing education of the accounting class, harmonization and international convergence of Accounting, and subjects for Accounting research. Lunedo et al. (2014) identified works on teaching-learning methods that require knowledge about IFRS.

Regarding the faculty members of Accounting subjects, Amaral, Costa and Campos (2010), they identified that several faculty members did not consider themselves prepared for the changes required by IFRS. Despite this acknowledgment of capacity constraints, most of faculty members already rated the convergence process as meaningful and, over time, began to feel prepared to teach, although they recognized that Brazilian educational institutions would not be prepared to subsidize this process (Fernandes et al., 2011).

Reis, Nogueira and Bim (2014) feature that faculty have knowledge about the changes; however, they would still presented certain resistance to the promotion of conceptual changes. Machado, Kuhn and Machado (2014) identified low level of knowledge and outdated professors in relation to IFRS, and could be improved by participating in new update courses on international standards Kuhn, Machado and Machado (2014).

The incorporation of IFRS in education, with quality, means improving school curricula, because even at the beginning of the convergence process, the syllabus of International Accounting undergraduate courses Niyama et al. (2008), which persists nowadays, since there is low adherence of HEIs in Brazil in relation to CPCs, as found by Alves et al. (2017).

In contrast, the research by Lima, Costa and Santana (2015) identified curricula aligned with each other and with the knowledge suggested by international organizations. Cunha, Guidini and Klann (2017), when relating the discipline of Accounting Theory and the convergence with international standards reported the most emphasized content by professors in graduate school (pós-graduação).

Regarding the opinion of students, in 2007, Niyama, Mendonça and Aquino (2007) revealed the incipience in the academic field of the subject "International Accounting". In 2014, Reis, Nogueira and Bim (2014) revealed that, although the absolute majority of the students had knowledge about the existence of the referred convergence process, the domain was mainly 
related to formal issues, such as the nomenclature of the corporate groups, to the detriment of conceptual aspects.

The research by Toigo et al. (2014) revealed that familiarity with the accounting standard is essential for the proper judgment and interpretation of CPCs. In this sense, in 2016, Nunes, Marques and Costa (2016) identified a low rate of correct answers to questions about basic concepts present in the Brazilian Accounting Standards, which corroborates the findings of Gomes et al. (2015) regarding the unsatisfactory knowledge of the students related to the subject.

The individualized results of the research do not allow the generalization of the findings to a general diagnosis of the consequences concerning the convergence of the accounting standard in accounting education, considering the sample limitation of the period. These were the main arguments for indications of continuity of the research (Amaral, Costa, \& Campos, 2010; Reis, Nogueira, \& Bim, 2014; Nunes, Marques, \& Costa, 2016; Cunha et al., 2017).

The teaching of accounting standards converged to international standards and other curricular knowledge of Accounting courses, are the suggested research about the nature of the difference in the level of knowledge between faculty members and the actions that improve teaching levels and effectiveness (Gomes et al., 2015; Kuhn, Machado, \& Machado, 2014; Machado, Kuhn, \& Machado, 2014; Nunes, Marques, \& Costa, 2016). However, it is expected that it has already overcome the limitations perceived by Araujo et al. (2014), regarding faculty members and students about the specific content.

After all, the evaluation process needs to be constantly analyzed, including consideration of the faculty member qualitative opinions (Cunha et al., 2017). These are considered as key elements to discuss teaching and changes with the advent of IFRS, with its nuances ranging from hiring or qualification stricto sensu (Alves et al., 2017)

The main concepts related to international standards seem to be incorporated into the teaching process, but the completeness of the adoption of the latest standards depends on further analysis (Amaral, Costa, \& Campos, 2010), including the scope proposed for the course, individually by the education institutions (Niyama et al., 2008), or in specific subjects to convergence (Alves et al., 2017; Cunha et al., 2017).

Convergence to international standards has led to the adoption of judgments to consider the essence over the form, and it is necessary to consider that students in Accounting are prepared to make the right decision. It is incumbent on broadening the verification of this judgment on the diversity of standards adopted (Toigo et al., 2014), and especially on the student's ability to make technical decisions - their behavior (Ettore, Silva, \& Macedo, 2017).

Matos et al. (2012) highlight the need to address methodological tools and epistemological characteristics that can be applied in the area. Despite of this, a differential is not perceived in relation to other accounting knowledge, so it would be a more general research on teaching techniques and methods. The potential of the most diverse researches cannot be summarized, but it is important to maintain the object, which, in the end, is whether the incorporation of international standards improves the quality of accounting education (Marassi, Fasolin, \& Klann, 2018).

\section{Final Considerations}

The present study aimed to analyze the teaching of accounting sciences in view of the convergence to international accounting standards, from the perspective of scientific production. The study of international standards is relevant due to the changes in the accounting process resulting from them. Greater transparency in information has required better prepared professionals who are able to adapt to these new accounting standards and this necessarily involves the educational issue. 
The research findings corroborate the context identified by Matos et al. (2012) within the scope of international journals. Studies on the subject "teaching and IFRS" should be considered current, relevant and in need of further research. The journals with the largest number of articles selected are the Journal of Accounting and Controlling (Revista de Contabilidade e Controladoria), Journal of Accounting Universe (Revista Universo Contábil) and Journal of Contemporary Accounting (Revista Contemporânea de Contabilidade), and 30\% of the articles are in the group of the best journals.

This piece of knowledge is very germinative for its authors, of these, $30 \%$ have a doctorate or post-doctorate degree, but there is also much acceptance of authorship articles by researchers in training - from undergraduate students (bacharelandos) to doctoral students (doutorandos). Despite the authorships pulverization, the most productive authors identified were Niyama, Botelho and Klann. The level development of education in accounting area directly affects the level of economic development of society. The increase of the level of qualification of accounting professionals - in the broad sense - will be able to improve the social perception of the profession and the quality of information generated for society.

In the universe of accounting research on IFRS, there are few that address the relation between the adoption of international standards and education, a current issue, relevant and in need of further research. Challenges in the field of accounting education, especially those related to the qualification of faculty, students and curriculum structure need to be overcome.

The results contribute to the literature and practice by permitting to recognize difficulties and opportunities in the incorporation of the new legislation or international standards for academic data, which may be mitigated in future cases. One of the potential future incorporation could be the full adoption of Noclar - Responding to Non-Compliance with Laws and Regulations (Sallaberry \& Flach, 2019).

The change in accounting standard predominantly applies practical empiricism to the curriculum, instruction, and teaching methods (Matos et al., 2012), with relevant reliance on continuing education in the accounting classes and update (Cella, Rodrigues, \& Niyama, 2011; Kuhn, Ax, \& Ax, 2014). Such a relevant change affects the student and the faculty member with the loss of confidence in their capacity (Amaral, Costa \& Campos, 2010), maintaining great resistance to the change (Reis, Nogueira, \& Bim, 2014), sometimes surpasses perception and affects the faculty's level of knowledge (Kuhn, Machado, \& Machado, 2014; Nunes, Marques, \& Costa, 2016).

After a broader time window, the results developed reveal the process of incorporating international accounting standards into the profession and academic data. In the end, the papers show greater difficulty in the time lapse closest to the changes of the standard, both in students and faculty members. The construction of knowledge models mainly for faculty members tends to take longer to assimilate different concepts to those already intricate in cognitive processes.

Over time, the results demonstrate improvements, considering that traditional education has already suffered quality limitations with time. Some limitations found for some time already presented more robust results. The behavior is limited, but not exclusive to the adoption of the new standards, while the approach of the various converged accounting standards, needing to consider to what extent of standards the pedagogical project indicates the approach.

Para pesquisas futuras, sugere-se a avaliação do nível de capacitação docente em relação às normas internacionais de contabilidade aplicáveis no Brasil, bem como estudos comparativos do nível de qualificação docente e do grau de conhecimento discente, simultaneamente, quanto às IFRS.

For future research, it is suggested to evaluate the level of faculty training in relation to the international accounting standards applicable in Brazil, as well as comparative studies of the level of faculty qualification and the level of student knowledge, simultaneously, regarding IFRS. 


\section{References}

Almeida, L. F. C., Machado, M. R. R., Machado, L. S., \& Zanolla, E. (2017). Análise Bibliométrica da Produção Científica Brasileira em Contabilidade Tributária. Contexto Revista do Programa de Pós-Graduação em Controladoria e Contabilidade da UFRGS, 17(35), 36-54.

Alves, D. S., Kronbauer, C. A., Ott, E., \& Thomaz, J. L. P. (2017). O ensino dos CPCs nos cursos de ciências contábeis em instituições de ensino superior do Brasil. Revista Contemporânea de Contabilidade, 14(32), 48-70.

Amaral, M., Costa, C., \& Campos, F. (2010). Capacitação Profissional: um Estudo Sobre a Adoção das IFRS Normas Internacionais de Contabilidade Nas Instituições Particulares de Ensino Superior do ABC. Revista Contemporânea de Contabilidade, 2(1), 117-139.

Araújo, K. D. de, Cornacchione Junior, E. B., Reginato, L., \&Suzart, J. A. da S. (2014). Percepção dos Impactos da Adoção das IFRS na Contabilidade Gerencial sob a ótica dos Professores de Programas de Stricto Sensu em Contabilidade. Revista Universo Contábil, 10(2), 105-124.

Bardin, L. (2016). Análise de Conteúdo. São Paulo: Edições 70.

Barth, M. E. (2008). Global Financial Reporting: Implications for U.S. Academics. The Accounting Review, 83(5), 1159-1179.

Brasil (2004). Ministério da Educação. Resolução CNE/CES 10, de 16 de Dezembro de 2004. Institui as Diretrizes Curriculares Nacionais para o Curso de Graduação em Ciências Contábeis, bacharelado, e dá outras providências. Disponível em:

$<$ http://portal.mec.gov.br/cne/arquivos/pdf/rces10_04.pdf>. Acesso em: 05 nov. 2013.

Cella, G., Rodrigues, J. M., \& Niyama, J. K. (2011). Contabilidade Internacional - análise dos periódicos internacionais sobre pesquisas em educação contábil face à convergência e globalização. Revista Contemporânea de Contabilidade, 8(15), 177-198.

Conselho Federal de Contabilidade - CFC (2019). Resultados. Disponível em: https://cfc.org.br/wp-content/uploads/2017/11/Resultadofinalporexame.pdf

Costa, P. S., Gomes, G., Braunbeck, G. O., \& Santana, M. E. G. (2018). Um safari no Brasil: evidências sobre o ensino baseado na estrutura conceitual. Revista Contabilidade \& Finanças, 29(76), 129-147.

Costa, J. A., Theophilo, C. R., \& Yamamoto, M. M. (2012). A Aderência dos Pronunciamentos Contábeis do CPC às Normas Internacionais de Contabilidade. Contabilidade, Gestão E Governança, 15(2), 110-126.

Cunha, L. C., Guidini, A., \& Klann, R. C. (2017). A Disciplina de Teoria da Contabilidade e a Convergência às Normas Internacionais de Contabilidade: Percepção dos Professores dos Programas Stricto Sensu em Contabilidade. Pensar Contábil, 19(68), 4-16. 
Damascena, L. G., Duarte, F. C. L., \& Paulo, E. (2017). Meta-Análise dos Efeitos da Adoção das IFRS na Qualidade da Informação Contábil no Brasil. Revista de Contabilidade do Mestrado em Ciências Contábeis da UERJ, 22(1), 28-48.

Ding, Y., Hope, O. -K., Jeanjean, T., \& Stolowy, H. (2007). Differences between domestic accounting standards and IAS: measurement, determinants and implications. Journal of Accounting and Public Policy, 26, 1-38.

Epstein, B. J., Mirza, A. A. (2006). IFRS: Interpretation and Application of International Financial Reporting Standards. New Jersey: John Wiley \& Sons.

Ettore, L. A. G., Silva, C. A. O., \& Macedo, M. A. S. (2017). Análise do Comportamento de Futuros Contadores Frente à Ocorrência do Efeito Formulação/Framing e de Seus Vieses: Um Estudo com Foco na Adoção das IFRS no Brasil. Contexto - Revista do Programa de PósGraduação em Controladoria e Contabilidade da UFRGS, 17(35), 19-35.

Fajardo, V., \& Frederico, G. (2015). 11\% dos cursos de graduação tem conceito abaixo da média. Disponível em: https://g1.globo.com/educacao/noticia/11-dos-cursos-de-graduacaotem-conceito-abaixo-da-media-diz-mec.ghtml

Fernandes, B. V. R., Lima, D. H. S., Vieira, E. T., \& Niyama, J. K. (2011). Análise da Percepção dos Docentes dos Cursos de Graduação em Ciências Contábeis do Brasil Quanto ao Processo de Convergência às Normas Internacionais de Contabilidade Aplicadas No Brasil. Revista de Contabilidade E Controladoria, 3(3), 24-50.

Gill, L. M. (2007) IFRS: Coming to America. Journal of Accountancy, 70-73.

Gomes, M. da S. G., Cruz, T. S. da, Souza, L. E., \& Gomes, I. B. (2015). Nível de Conhecimento dos Futuros Profissionais de Contabilidade do Estado da Bahia: Uma Análise à Luz dos Conceitos Básicos Presentes nas Normas Brasileiras de Contabilidade. REUNIR, $5(2), 104-121$.

Hernandes, D. C. R., Peleias, I. R., \& Barbalho, V. F. (2006). O professor de contabilidade: habilidades e competências. Didática do Ensino da Contabilidade-Aplicável a outros Cursos Superiores. São Paulo: Saraiva, 61-119.

Howieson, B. A. Accounting practice in the new millennium: is accounting education ready to meet the challenge? The British Accounting Review, [S.1], v. 35, n., 2, p. 69-103, 2003.

Kuhn, J., Machado, M. R. R., \& Machado, L. de S. (2014). Avaliação do Conhecimento dos Docentes da Grande Goiânia sobre Pronunciamentos Contábeis. Revista de Contabilidade Do Mestrado Em Ciências Contábeis Da UERJ (Online), 19(2), 2-22.

Laffin, M. (2001). Ensino da Contabilidade: componentes e desafios. Anais In: Fórum Nacional de Professores de Contabilidade, 7., Rio de Janeiro.

Laffin, M. (2002). Formação continuada do profissional da Contabilidade. Jornal do Conselho Regional de Contabilidade do Estado de Santa Catarina, Florianópolis.

Lima, R. L., Costa, A. de J. B., \& Santana, C. M. (2015). Educação Contábil em Tempos de IFRS: Um Estudo de Caso entre uma Universidade Brasileira e outra Alemã. Revista de Gestão e Contabilidade de UFPI, 2(1), 61-76. 
Lopes, A. B., Martins, E. (2014). Teoria da contabilidade: uma nova abordagem. São Paulo: Atlas.

Lunedo, A. C. B., Kruger, S. D., Mazzioni, S., Lunedo, R., \& Folletto, E. P. (2014). As Características Das Publicações Brasileiras Sobre As IFRS E Os Pronunciamentos Contábeis Em Periódicos de Alto Impacto. Sociais E Humanas, UFSM, 27(2), 40-57.

Machado, L. de S., Kuhn, J., \& Machado, M. R. R. (2014a). Conhecimento dos Docentes de Contabilidade Sobre as Normas Internacionais. Revista de Contabilidade E Controladoria, $6(1), 28-42$.

Machado, M. C., \& Nakao, S. H. (2014). Influência das Diferenças Culturais, Econômicas e Sociais na Adoção das IFRS. Revista Universo Contábil, 10(1), 104-125.

Machado, V. N., Victor, F. G., \& Mattis, J. S. (2016). Ativos biológicos: uma análise da aderência ao CPC 29 pelas companhias listadas na BM\&FBOVESPA de 2007 a 2015. Contexto - Revista do Programa de Pós-Graduação em Controladoria e Contabilidade da UFRGS, 16(34), 35-52.

Marassi, R. B., Fasolin, L. B., \& Klann, R. C. (2018). O Ensino de Teoria da Contabilidade no Brasil após o Processo de Convergência das Normas Internacionais de Contabilidade sob a Ótica dos Docentes do Estado do Paraná. Contabilidade Vista \& Revista, 29(2), 18-41. https://doi.org/10.22561/cvr.v29i2.3821

Marion, J. C. O ensino da Contabilidade, Atlas.

Marshall1, D., Dombrowski, R., Garner, M., \& Smith, Kenneth. (2010). The Accounting Education Gap, The CPA Journal, 80(6), 6-10.

Martins, E., Gelbcke, E. R., Santos, A., Iudicibus, S. (2013). Manual de Contabilidade Societária. 2.ed. São Paulo: Atlas.

Matos, E. B. S., Niyama, J. K., Fernandes, J. L. T., \& Botelho, D. R. (2012). Um estudo sobre a pesquisa em educação contábil em periódicos internacionais: Temáticas envolvendo as normas internacionais de contabilidade. ConTexto, 12(22), 59-73.

Matos, E. B. S., Gonçalves, R.S., Niyama, J. K., \& Marques, M. M. (2013) Convergência internacional: análise da relação entre o processo normativo e a composição dos membros do IASB. Advances in Scientific and Applied Accounting, 6(1), 66-91.

Mattos, P. L. C. (2004). " Bibliometria": a metodologia acadêmica convencional em questão. RAE-eletrônica, 3(2), 1-6.

Miller, W. F., \& Becker, A. D. (2010). Why are accounting professors hesitant to implement IFRS?. The CPA Journal, 80(8), 63.

Miranda, G. J. (2011). Relações entre as qualificações do professor e o desempenho discente nos cursos de graduação em Contabilidade no Brasil (Tese, Universidade de São Paulo).

Miranda, G. J. (2010). Docência Universitária: Uma Análise das Disciplinas na àrea de Formação pedagógica Oferecidas pelos Programas de Pós-graduação Stricto Sensu em Ciências Contábeis. Revista de Educação E Pesquisa Em Contabilidade, 4(4), 81-98. 
Miranda, G. J., Santos, L. de A. A., Casa Nova, S. P. de C., \& Cornachione Junior, E. B. (2013). A Pesquisa em Educação Contábil: Produção Científica e Preferências de Doutores no Período de 2005 a 2009. R. Cont. Fin. - USP, 24(61), 75-88.

Mohamed, E. K. A., \& Lashine, S. H. (2003). Accounting Knowledge and Skills and the Challenges of a Global Business Environment. Managerial Finance, 29(7), 3-16.

Nascimento, S. G. O. de, Lopes, J. E. de G., Colauto, R. D., \& Pederneiras, M. M. M. (2014). Colonização da Contabilidade: um Estudo sobre o Processo de Convergência da Contabilidade Brasileira aos Padrões Internacionais. Revista Ambiente Contábil, 6(2), 134 151.

Needles, Jr, B. E., Cascini, K., Krylova, T., \& Moustafa, M. (2001). Strategy for Implementation of IFAC International Education Guideline No. 9:"Prequalification Education, Tests of Professional Competence and Practical Experience of Professional Accountants": A Task Force Report of the International Association for Accounting Education and Research (IAAER). Journal of International Financial Management \& Accounting, 12(3), 317-353.

Nganga, C. S. N., Botinha, R. A., Miranda, G. J., \& Leal, E. A. (2016). Mestres e Doutores em Contabilidade no Brasil: uma Análise dos Componentes Pedagógicos de sua Formação Inicial. Revista Iberoamericana sobre Calidad, Eficacia Y Cambio enEducación, 14(1), 8399. https://doi.org/10.15366/reice2016.14.1.005

Niyama, J. K. (2010) Contabilidade Internacional. 2.ed. São Paulo: Atlas.

Niyama, J. K., Botelho, D. R., Corrêa, B. M., \& Santana, C. M. (2008). Conhecimento de Contabilidade nos Cursos de Graduação em Ciências Contábeis: Estudo da Oferta nas Instituições de Ensino Superior das Capitais Brasileiras. RCO-Revista de Contabilidade E Organizações, 2(2), 100-117.

Niyama, J. K., Mendonça, A. C. dos S., \& Aquino, D. R. B. de. (2007). Estudo empirico da percepção dos alunos de graduação em Ciências Contábeis do Distrito Federal quanto às causas das diferenças internacionais no financial reporting das empresas. Revista Universo Contábil (Online), 3(2), 22-38.

Nossa, V. (1999). Formação do corpo docente dos cursos de graduação em contabilidade no Brasil: uma análise crítica. Caderno de Estudos, (21), 01-20.

Niyama, J. K., Silva, C. A. T. (2013). Teoria da Contabilidade. 3.ed. São Paulo: Atlas.

Nunes, I. V., Marques, A. V. da C., \& Costa, P. de S. (2016). Nível de Conhecimento dos Discentes em Ciências Contábeis Sobre o Pronunciamento Conceitual Básico. Revista Universo Contábil, 12(1), 87-104. https://doi.org/10.4270/ruc.2016105

Pazetto, C. F., dos Santos, V., \& Beuren, I. M. (2019). Abordagens da contabilidade gerencial em periódicos brasileiros. Enfoque, 38(1), 47.

Passos, I. C. (2011). Raciocínio crítico de alunos de graduação em Ciências Contábeis: aplicação do modelo instrucional de Richard Paul (Tese, Universidade de São Paulo). 
Pierre, K. S., Wilson, R. M. S., Ravenscroft, S. P., \& Rebele, J. E. (2009). The Role of Accounting Education Research in our Discipline - An Editorial. Accounting Education, $24(2), 123-130$.

Raupp, F. M.; Beuren, I. M. (2013) Metodologia da Pesquisa Aplicável às Ciências Sociais. In: Beuren, Ilse Maria (Org.) Como Elaborar Trabalhos Monográficos em Contabilidade: Teoria e Prática. (3 $3^{\text {a }}$ Ed,). São Paulo: Atlas.

Reis, L. G. dos, Nogueira, D. R., \& Bim, E. A. (2014). Convergência às Normas Internacionais de Contabilidade: uma Análise sob a Perspectiva Docente e Discente. Revista de Administração, Contabilidade E Economia Da FUNDACE, 43(9), 1-14.

Riccio, E. L.; Sakata, M. C. G. (2004) Evidências da globalização na educação contábil: estudo das grades curriculares dos cursos de graduação em universidades brasileiras e portuguesas. Revista Contabilidade \& Finanças, 15(35), 35-44.

Sallaberry, J. D. \& Flach, L. (2019). Percepção do Profissional Contábil sobre Operações Suspeitas de Lavagem de Dinheiro. In: 45th World Continuous Auditing \& Reporting Symposium, 2019, Florianópolis.

Semeasp (2018). Crise de nível superior. Disponível em: https://www.semesp.org.br/imprensa/crise-de-nivel-superior/

Silva, A. C. R. (2003) Metodologia da pesquisa aplicada à contabilidade: orientações de estudos, projetos, relatórios, monografias, dissertações, teses. São Paulo: Atlas.

Silva, J. P., Borges, T. J. G., Gonçalves, R. de S., \& Nascimento, D. V. R. do. (2017). Convergência ao Padrão IFRS e Suavização de Resultados em Empresas de Energia Elétrica. BASE - Revista de Administração e Contabilidade da Unisinos, 14(4), 281-296.

Silva, U. B., Santos, E. B., Cordeiro Filho, J. B., Bruni, A. L. (2014). Concepções pedagógicas e mudanças nas práticas contábeis: um estudo sobre o modelo educacional adotado em uma universidade pública e a formação crítico-reflexiva do contador. Revista de Contabilidade e Controladoria, 6(2), 54-66.

Sousa, R. L. S., \& Santos, O. M. D. (2017). Nível de Evidenciação das Instituições Financeiras à Luz das Exigências DOCPC 40 - Instrumentos Financeiros. Contexto - Revista do Programa de Pós-Graduação em Controladoria e Contabilidade da UFRGS, 17(35), 105122.

Toigo, L. A., Pletsch, C. S., Vogt, M., Degenhart, L., \& Klann, R. C. (2014). Características que Afetam o Julgamento dos Acadêmicos de Ciências Contábeis Quanto aos Pronunciamentos Técnicos do CPC. Revista Da UNIFEBE, 14, 155-170.

Vasconcelos, M. L. M. C. (1996). A formação do professor de terceiro grau. São Paulo: Pioneira.

Vendruscolo, M. I. (2015). Modelo pedagógico para o desenvolvimento de competências docentes em Contabilidade por educação à distância. Tese de Doutorado. Universidade Federal do Rio Grande do Sul, Brasil.

Watts, R. L., Zimmerman, J. L. (1986). Positive Accounting Theory. Englewood Cliffs: Prentice Hall. 
Weffort, E. F. J. (2005). O Brasil e a Harmonização Contábil Internacional. São Paulo: Atlas.

Zabala, A. (1998). A prática Educativa: como ensinar. Porto Alegre: Artmed.

Zortea, C. T., Galdi, F. C., Monte-mor, D. S., \& Beiruth, A. X. (2017). Eficiência do Mercado de Capitais Após a Adoção da IFRS no Brasil: Aplicando o Teste de Mishkin. Revista Contemporânea de Contabilidade, 14(32), 141-156. 